DOI: $10.20472 /$ IAC.2017.032.017

\author{
MULIN JEONG \\ Inje University, Korea, Republic of \\ HEYKYUNG PARK \\ Inje University, Korea, Republic of
}

\title{
A STUDY ON ELDERLY ATTITUDE AND COLOR PREFERENCE ON REPUBLIC OF KOREA NURSING HOMES.
}

\begin{abstract}
:
Rapid graying made the Korean government has enforced the Long-term care insurance in 2008 and related elderly nursing homes are ever increasing since.

The elderly nursing homes in Korea are focusing on quality rather than quantity, especially environmental supports.

Color environment design is one of the quality elements that improve the services of the nursing homes as well as the satisfaction of its residents. Therefore, reasonable planning will only be available after the element is studied.

The purpose of this research is to understand elderly consciousness on the nursing homes and their color preferences in order to provide baseline data for elderly nursing home plans.
\end{abstract}

\section{Keywords:}

nursing home / elderly / color preference 